Potravinarstvo Slovak Journal of Food Sciences

vol. 15, 2021, p. 585-591

https://doi.org/10.5219/1484

Received: 14 October 2020. Accepted: 9. June 2021.

Available online: 28 June 2021 at www.potravinarstvo.com

(C) 2020 Potravinarstvo Slovak Journal of Food Sciences, License: CC BY 3.0

ISSN 1337-0960 (online)

\title{
THE STATE AND THE SHARE OF RURAL WOMEN ON THE AGRICULTURAL ENTREPRENEURSHIP ACTIVITIES IN THE SLOVAK REPUBLIC
}

\author{
Zuzana Kapsdorferová, Silvia Jacková, Petronela Švikruhová
}

\begin{abstract}
The economic empowerment of rural women in the recent development of agriculture through entrepreneurship is considered an important challenge. Rural women often manage complex households and pursue multiple livelihood strategies. Their activities typically include cultivation of crops, farming animals, processing and preparing food, working for wages in agricultural or other rural enterprises, collecting fuel and water, engaging in trade and marketing, caring for family members, and maintaining their homes. The research aimed to collect up-to-date data on Slovak rural women dealing with business in the field of agriculture, women's role and status in society in rural areas, on the farm, women's participation in education, training, and agricultural services. The main focus is dedicated to their share on the management of agricultural entities, land cultivation, employment of rural women and men, and their deal on the selected entrepreneurial activities of Slovak agriculture. Women doing business in agriculture dispose of with considerable knowledge and experience in the agricultural and food sectors. The realized research showed that the scale of farms managed by women is 325 hectares. Rural women in the surveyed group are taking care of about $2.5 \%$ of the total area of agricultural land in Slovakia and they are employing $2.40 \%$ of the working forces in the agricultural sector in Slovakia. According to our survey, rural women are underrepresented in managerial and ownership positions of agricultural entities.
\end{abstract}

Keywords: agribusiness; agricultural entities; rural women; gender gap; agricultural entrepreneurial activities

\section{INTRODUCTION}

The mission and tasks of rural women are differentiating according to individual states, regions, continents. Despite this, women everywhere in the world have to face in their professional and private lives various specific limitations. According to FAO (2011), women represent approximately $43 \%$ of the world's working forces in agriculture, but they do own less than $20 \%$ of agricultural land in the world. If women would have a better approach to financial and production sources, across the world, this could significantly downsize the number of people affected by hunger. Moreover, the nutrition status of the world population would immensely improve owing to the higher yields of about 20 to $30 \%$. This would virtually mean fewer hungry and undernourished people about $12-17 \%$ in the world (FAO, 2011). Historically rural women always played in the society important key role, both in the care of the members of their families as well as in crop production together with animal rearing. Throughout the millennials was, and this is persisting, the great share of rural women at the arrangement of nutrition in families through their works in kitchens, on fields, gardens, orchards, forests, and in stables. If the rural women would be more involved in agriculture and rural development as the owners of the farms or managers, this would lead to the improvement of their social status and upgrade the living standards of their families. Very essential is also the fact that this would generate new working opportunities for females and men. Therefore, it is desirable for women living and acting in the countryside to create appropriate space for their selfrealization and education opportunities through which, the involvement of rural women in entrepreneurial activities can be reasonably upgraded. The main problems of rural women can be divided into four main categories economic, social, family level, and individual. Most of the problems are connected to the social and political change and transition taking place in the countries. For many rural women and families, the transition from one system to another has meant increased economic problems and a loss of paid labor and unemployment. In private agriculture, the main problem is low-income levels. For many rural women, the economic problem is dependence on their husband's income. Social problems are connected with economic problems; unemployment and a lack of income are usually connected with malnutrition, illness, and alcoholism. In many CEE countries, the social infrastructure in the villages was connected with the agricultural production system; giving up the state and cooperative farms led to the loss of 
social services such as kindergartens as well as health and maternity care provided by the state and cooperative farms. In addition, many cultural activities were connected with the state and cooperative farms and have been lost during the transition (Siiskonen, 1996). The objective of the submitted scientific article is to evaluate the status of the agricultural business environment in the Slovak Republic with a focus on those enterprises in which the owners are women or eventually in which the women are undertaking managerial positions. Furthermore, the objective is to find out the share of rural women in agricultural entrepreneurial activities.

\section{Scientific hypothesis}

This research paper aims to collect up-to-date data on Slovak rural women dealing with business in the field of agriculture, women's role and status in society, in rural areas, on the farm, and women's participation in education, training, and agricultural services.

Several hypotheses were formulated:

Hypothesis 1: Rural women have equal business rights when asking for various kinds of state or EU supports.

Hypothesis 2: We assume that most women operate their businesses in the form of an individual farmer.

Hypothesis 3: There exists dependency between the size of farms in hectares and the legal business forms.

Hypothesis 4: There exists a dependence between several years of practical experience of rural women in agriculture and the legal form of business.

\section{MATERIAL AND METHODOLOGY}

In this part of a scientific article, we do identify the share of rural women in various economic activities performed in the frame of agricultural and food sector, as well as the share of women on the acreage of agricultural land, number of agricultural entities with different legal statuses, or their share on the number of employees. Moreover, we deal with the evaluation of rural women's share in the rearing of farm animals. For rendering primary data was as the main research technique used questionnaire survey, furthermore with rural women had been conducted face-to-face interviews. The gathering of data was carried out in two rounds; the first round was focused on a pilot survey which was carried out during summer 2017. In this way, it was tested the functionality and correct construction of the questionnaire survey. Furthermore, following above mentioned steps, those agricultural companies that were led by women have been approached with consistent analytical and synthetical research in 2018. The total number of agricultural enterprises involved in the questionnaire survey was 130 . The following formula was used to estimate the minimum number of samples $(n)$ (Szreder, 2004):

Where:

$$
n=\frac{\frac{1}{4} \times N}{N \times \frac{d^{2}}{z_{\alpha / 2}^{2}}+\frac{1}{4}}
$$

$N$ - number of entities; $\mathrm{Z}^{2}{ }_{\alpha / 2}$ - the value of random variable $\mathrm{Z}$ of normal standard distribution; $d$ - statistical error. minimum sample size was set at 116 business entities. After the collection of required data, this had been classified, processed, and evaluated. To statistically elaborate the obtained data, was utilized program XLStat and as the key statistical methods had been applied nonparametric statistical tests such as Kruskal-Wallis test Fisher's test, Friedman's test, and Dunnett method. Computation of the Kruskal-Wallis test involves arranging the score from all the groups in order and assigning ranked scores. The sum of ranks is computed for each group and used in the equation below to determine whether there are group differences $i$ the ranks (equation adapted from Siegel and Castellan, 1988).

$$
K W=\left\lceil\frac{12}{N(N+1)} * \sum_{i=1}^{k} n_{i} \bar{R}_{i}^{2}\right\rceil-3(N+1)
$$

Where:

$k$ - represents the number of groups; $n_{i}$ - represents the number of cases in the $i$ group; $\bar{R}_{i}$ - mean rank from the $i$ group; $N$ - represents the total sample size.

The test determines whether the medians of two or more groups are different. Like most statistical tests, you calculate a test statistic and compare it to a distribution cutoff point.

Rural women from the surveyed group have in general university education, mainly in the field of agriculture. The average age of female farmers is 49 years. Rural women are doing their business as the individual farmers managing the micro-companies, or small companies, although they are prepared to manage even larger companies, so they are daring enough to take over a larger responsibility in the position of managerial staff. This later is in recent years considered as a very natural trend as the women more and more are managing larger companies and occupy seats on the top managerial positions. Concerning the average size of farms managed by rural women, this achieves 325 hectares of agricultural land. In most cases, the rural women in their business companies own only a small part of the land and the rest is rented for a long-term period from the local community, individual owners, or from State Land Fund. Rural women are doing their business mainly in the field of crop production rather than in animal production. Also, they do concentrate their effort on the provision of services, such as agro-tourisms, or the sale of primary or processed agricultural products. Doing agribusiness activities means from rural women's value point of view, first of all, continuation in family traditions. They like this work since they grew up with it. If rural women would be once more given the opportunity to select the field of their entrepreneurial activities, they will again commence with business linked to agriculture and food processing. It should be emphasized that businesswomen in agriculture do have a wide experience and knowledge in the given fields. The average years of practical experience are recording 23 years. Rural women consider themselves as emancipated personalities and they do not feel any discrimination concerning their business activities.

In the studies, it was assumed that the maximum statistical error of the results may amount to $+/-5 \%$. The necessary 


\section{Statistical analysis}

The selection of tests is designed particularly because of variables in research. The attention is paid to the formulation of hypotheses (null and alternative) and to determine the level of significance. The collected data were processed by using Microsoft Excel and subsequently evaluated in the statistical program XL Stat. The formulated hypotheses were tested by applying the following statistical tests:
1) Kruskal Wallis test
2) Friedman's test
3) Fisher's test and
4) Dunnett method

In hypothesis testing, if the p-value is lower than a significant level, in the case of XL Stat software by Addinsoft (version 2019.3.2), it is 0.05, the null hypothesis was rejected and the alternative hypothesis was confirmed.

\section{RESULTS AND DISCUSSION}

Women possess good personality traits for business, such as excellent organizational and communication skills, they are well motivated, dedicated, consistent, and able in an empathic way to navigate their colleagues into positive thinking and to lead them to high performances (Kadlečíková and Veselá, 2011). Women are farmers, workers, and entrepreneurs, but almost everywhere they face more severe constraints than men in accessing productive resources, markets, and services. This "gender gap" hinders their productivity and reduces their contributions to the agriculture sector and the achievement of broader economic and social development goals. Closing the gender gap in agriculture would produce significant gains for society by increasing agricultural productivity, reducing poverty and hunger, and promoting economic growth (Patil and Venkatachalapathi, 2018). Rural women's role and mission in agriculture are not irreplaceable at the land cultivation and achievement of the nutrition for inhabitants (Bujňáková, 2010). According to FAO (2011) the most significant recent challenges in agriculture, besides the others, are that women have no sufficient resources and opportunities for their own business. In various states is very complicated to assign, that what is the share of rural women in agricultural activities (Doss, 2011). A very important precondition for rural women 's business the education. In this connection, they state that tertiary agricultural education achieved in 2012 about $8.4 \%$ more women than men, by this they proved to have a considerable place in the economy, also in science, and politics (Jacková et al., 2016). In line with authors Schneiderová (2015) states that from universities are graduated significantly more women than men, even with better study results. The same author concluded that women-entrepreneurs in the same age category are achieving the top positions in business as their male colleagues. This means the age around 50 years with already completed long career rout around of $20-25$ years in the agribusiness sector.

In the Slovak countryside is living $42.1 \%$ of women of productive age, (ILO 2018, Fares et al., 2007). In the years 1999 - 2008 was the share of the European women in the age of $15-49$ years at the level of $49.5 \%$. In the rural areas, this indicator was a little bit lower (47.7\%), while in cities this achieved even 50.4\%. In Slovak circumstances have been achieved analogical results about first indicator $49.2 \%$, then in countryside $48.2 \%$ and finally in the city agglomerations, it was $50.1 \%$. Grznár and Szabo, (2015) and Buchta (2013) highlighted that a serious challenge is employees' sharp decline in the agricultural sector. These authors do propose the development of supporting investment programs that will encourage the employment of young and female farmers.

The share of unemployed rural women in Slovakia is rather high. In 2012 this represented even 18.4\%. During the period 2007 - 2014 the average share of unemployed rural women dropped by $16.55 \%$. In comparison with other states, rural women's employment was more favorable e.g. in the Czech Republic with 8.19\% and Austria with 3.53\% (ILO, 2018). In the environment of the Slovak Republic comparing with average data, fewer women are involved in entrepreneurial activities in agriculture and food processing. According to the Statistical Office of the Slovak Republic in agribusiness is employed only $26.5 \%$ of women as the physical working staff, managers, or owners of the farms (Statistical Office of Slovak Republic, 2018). Women in the past were working behind the men and they were invisible on the farm for decades as farmers' wives with their unpaid work. Historic inequality in ownership and heritage of land and control are cause and consequence of the opinion that farming is not considered a suitable career for women (Robertson, 2017).

Stemming from the above-cited literature sources, it would be important to achieve a more balanced equal status of men and women in agriculture and to shift the attitudes in favor of an increasing number of rural women who will run their business entities.

\section{The Share of Rural on the Development of Agricultural Activities}

In this part of a scientific article, we do identify the share of rural women in various economic activities performed in the frame of agricultural and food sector, as well as the share of women on the acreage of agricultural land, number of agricultural entities with different legal statuses, or their share on the number of employees. Moreover, we deal with the evaluation of rural women's share in the rearing of farm animals.

\section{The Share of Rural Women on the Cultivated Agricultural Land}

In 2016 the acreage of the utilized agricultural land represented 1918878 hectares. In comparison with the year 2015, there was a noted decline of about 2685 hectares $(0.14 \%)$ and in comparison with the year 2012, the decline was even about 8572 hectares. The acreage of tillage in 2016 was 1347293 hectares, comparing with 2012 it was noted downsizing about 12686 hectares, so every day in the indicated period was lost 9.2 hectares of tillage. This result is documenting irresponsible behavior to the environmentally friendly approach about the care of natural resources, which to the end can very seriously harm the state food security very soon.

In 2017, women involved in undertaken research, in total cultivated 39418,25 hectares of land $(2.05 \%$ from the overall area of agricultural land). This percentage can be 


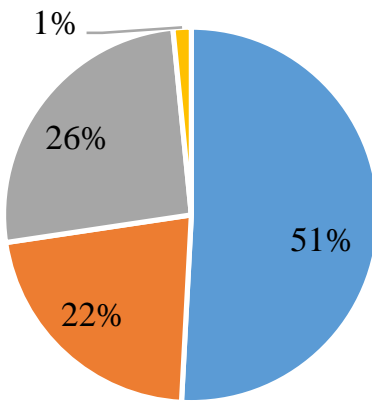

- Individual Farmer

- Cooperative

- Limited Liability Company

Figure 1 Classification of Companies According of Legal Forms in \%. Note: Own processing based on questionnaire survey.

considered as a negligible extend and it is proof that the involvement of rural women in agricultural entrepreneurial activities is so far very low. The same is valid about the number of farms managed by rural women. Taking into consideration that in Slovakia the number of total agricultural entities is 27833 (Green Report, 2017) and that our research had been involved 130 farms managed by rural women, then their share on the management and ownership of agricultural entities is only $0.46 \%$. The size of one agricultural entity managed by the rural woman in our case is 325 hectares. This is significantly higher than the Slovak average with 80.7 hectares. In this respect, it should be positively regarded the courage of rural women to establish larger entrepreneurial entities with determination to further expand their business. The management of larger enterprises is more demanding from a managerial point of view, but it has to be reiterated, that women from our research group exceed with excellent organizational traits, great determination, and intuition.

\section{The Share of Rural Women on Agricultural Employment}

The share of agriculture in total employment in the national economy was just 2.89\% in 2017 (Green Report, 2017). This result is connected with the permanent outflow of working forces from the sector to the other branches of the national economy which commenced with the transition process of the national economy and continued with country accession to the EU.

In 2017 was employed in Slovak agriculture with 52,5 thousands of employees, from which women represented 13,1 thousand (24.95\%) and men 39,4 thousand (75.05\%) (Green Report, 2017). The number of women employed in agriculture in the analyzed period had relatively stable development, the least women worked in the sector in 2015 (12,8 thousand).

The agricultural entities led by women in our research group are employing in total 1471 persons, this presents $2.40 \%$ from the overall number of people employed in agriculture (2017). Stemming from the total number of women employed in agriculture (13,1 thousand), rural women in our group employ merely $3.48 \%$ of them.
However, it should be reiterated that on average, rural women who manage the agricultural entities in our group employ $30.99 \%$ (456) of women, which is a slightly higher share as it is prevailing in the sector (24.95\%). The results of our survey claim that women in their business incline to prefer female working forces. In this case, we cannot perceive such an approach as a negative trend from the gender point of view. This is more about the cause interlinked to the finalization of agricultural commodities, such as processing and selling of ready-made products, as well as providing services connected to the rural businesses, where is more preferable female working force. This is also another reason why it is important to support the entrepreneurial activities of women in the agricultural and food processing sector because the materialization of this approach will be created more employment opportunities both for women and men in the countryside.

\section{The Number and Types of Agricultural Business Entities Managed by Women}

As it was previously mentioned in Slovak agriculture operated 27833 entities in 2017 which applied various legal business forms. This is representing a share of $1.16 \%$ of the overall number of agricultural entities in the state.

In the surveyed sample the strongest group is represented by female individual farmers with 63 farms, this is almost half of the entities in our research group. (48.5\%). Few women are operating their businesses in the form of Limited liability companies (Ltd.), in total 32 companies (24.6\%). In the legal form - cooperative is doing their agribusiness 27 companies (20.8\%). With trade certificates are operating 6 respondents $(4.6 \%)$ and only 2 entities from the research group $(1.5 \%)$ have indicated that they provide their business in the shareholding companies (Figure 1).

The size of cultivated land in an agricultural business entity was analyzed concerning the legal business form of the company. The objective was to recognize, whether there are some connections or differences concerning the size of companies and applied legal business forms. For this purpose, it was utilized Kruskal-Wallis test (Table 1).

Kruskal-Wallis test is confirming that there do exist differences between hectares of cultivated land and the applied legal forms of business. For the sake of more detailed exploration was this test completed by the Dunnett method.

Table 1 Kruskal- Wallis Test for Recognition of Dependence between Scale of Entities and Legal Forms.

\begin{tabular}{lr}
\hline $\mathrm{H}_{0}$ & $\begin{array}{r}\text { There are no statistically significant } \\
\text { differences between the size of farm in } \\
\text { hectars and the legal business forms. }\end{array}$ \\
\hline $\mathrm{H}_{1}$ & $\begin{array}{r}\text { There are statistically significant } \\
\text { differences between the size of farm in } \\
\text { hectars and the legal business forms. }\end{array}$ \\
\hline$p-$ value & H1 is accepted \\
Test & \\
\hline
\end{tabular}

Note: Own results, XL Stat. 
Dunnett's method separated the agricultural entities into two groups, A and B. Those in group A have statistically significantly less land than the entities involved in group B. The least land has companies that are doing their business upon the trade certificates, and the biggest sizes in hectares have shareholding companies and cooperatives.

There is a statistically significant difference according to the company size in hectares of agricultural land among shareholding companies and cooperatives on the one side and on the other side between Ltd., individual farmers, and those who do the business upon the trade certificate.

Furthermore, our goal was to ascertain that what kind of effect has the number of years of manager's experience in agriculture on the selected legal forms of business by rural women. For this purpose, was applied Kruskal-Wallis test (Table 2).

The dependence between several years of practical experience of rural women in agriculture and the legal form of business confirmed by the Kruskal-Wallis test was also proved and more profoundly specified by the Dunnett method. According to Dunnett methods have been companies divided into two groups. Women who are managing the companies in the first A group have significantly fewer years of practical experience in agriculture than the women who are managing the companies in group B. The last years of practical experience in agriculture have women in the Ltd., the most years the women who are managing shareholding companies and the cooperatives. The highest statistically significant difference was in the number of years in agriculture between the women in the Ltd. and the women who are leading the cooperatives.

From this analysis are stemming two conclusions:

1. 1.Rural women are willing to take over higher responsibility which is connected to the management of the agricultural entities on a larger scale;

2. Rural women do prefer to manage companies whose legal business forms are requiring a wide scope of technical, financial, managerial, and leadership capacities.

3.

\section{Production focus of rural women}

In business activities, rural women concentrate on the balanced approach both to crop and animal productions. They have no intention to simplify their production programs by cultivating monocultures typical for industrial agriculture.

The ratio between crop and animal productions is rather equal, whereas the rural women dedicate their business efforts to the cultivation of crop breeds in $77.70 \%$ of cases, while with animal rearing deal $64.60 \%$ of women. For women of our surveyed group, except for traditional agricultural production is the characteristic sale of the agricultural products (30.50\% of respondents). With this is connected the processing of agricultural primary products. This activity is ranked as number 4 with a share of $20.80 \%$. An almost identical result was achieved at the sale of agricultural products. This is once more activity typical for the female working force, as the women have better assumptions for providing a different kind of services in a more complex way. Less significantly is represented
Table 2 Kruskal- Wallis Test for Exploration of Dependence between Number Years of Experience in Agricultural and the Legal Form of Business Entities.

\begin{tabular}{|c|c|}
\hline $\mathrm{H}_{0}$ & $\begin{array}{l}\text { There are no statistically significant } \\
\text { differences between number of years of } \\
\text { experiences in agriculture and the selected } \\
\text { legal business forms. }\end{array}$ \\
\hline$\overline{\mathrm{H}_{1}}$ & $\begin{array}{l}\text { There are statistically significant } \\
\text { differences between number of years of } \\
\text { experiences in agriculture and the selected } \\
\text { legal business forms }\end{array}$ \\
\hline$p$-value & 0.0172 \\
\hline $\begin{array}{c}\text { Test } \\
\text { Conclusion }\end{array}$ & H1 is accepted \\
\hline
\end{tabular}

Note: Own results, XL Stat.

Table 3 Production focus of companies managed by rural women in 2017.

\begin{tabular}{lcr}
\hline Production focus of company & Number & In [\%] \\
\hline Crop production & 101 & 77.70 \\
Animal production & 84 & 64.60 \\
Processing of agricultural & 27 & 20.80 \\
products & & \\
Sale of the agricultural products & 41 & 30.50 \\
Agrotourisms & 15 & 11.50 \\
Providing of services & 26 & 20.00 \\
Extension services & 7 & 5.40 \\
Rent of agricultural equipment & 3 & 2.30 \\
Others & 3 & 2.30 \\
\hline
\end{tabular}

Note: Own results, XL Stat.

Table 4 Number of farm animals reared by rural women and its share on the total number of farm animals in Slovak Republic in 2017.

\begin{tabular}{lcr}
\hline Farm animal category & Number & In [\%] \\
\hline Livestock & 9.789 & 2.19 \\
Pigs & 274 & 0.05 \\
Sheep & 14.915 & 4.04 \\
Goats & 406 & 1.12 \\
Poultry & 240.815 & 1.99 \\
Horses & 141 & 2.20 \\
\hline
\end{tabular}

Note: Own results, XL Stat.

agrotourism with $10.50 \%$. Interestingly, women doing their business in the countryside alongside production activities are oriented also on the extension services in such an area as the correct accomplishment of the requests for direct payments and other subsidy's entitlements, or the work with information technologies.

The rent of the agricultural machinery is represented less significantly, just with $2.30 \%$ (Table 3 ).

The number of farm animals reared by rural women and their share of the total number of farm animals in 2017 is mentioned in Table 4. The share of women in livestock 
production is only $2.19 \%$. The lowest share is noted by rural women in the production of swine with $0.05 \%$. With rearing of swine deal only 6 companies. Poultry represents $1.99 \%$ of the total number of this breed in Slovakia, while the number of goats is represented by the share of $1.12 \%$.

We presume that these results are influenced by the fact that the majority of rural women are doing their business by farming system, moreover in the less favorable natural areas. Therefore, women strive to the rear first of all sheep, goats, as well as cows, to process milk on the finalized food commodities, which would be sold in their farm shops, or on the farm, markets organized nearby of their farms. Except for these, there is the opportunity created in last years to directly place local food products in the supermarkets. With regard, the horse rearing recent trend is very much interlinked with the diversification of agricultural production to create riding areas with other leisure time activities, which are very popular in the last years. Our results confirm that businesswomen prefer the finalization of products with higher added value. In comparison with agribusiness men, rural women prefer traditional agricultural production which combines crop and animal production intending to take advantage of the interconnection of these two basic farming branches.

Agriculture and food production do represent one of the most important sectors of the national economy and fulfill a key role in the achievement of the food security of citizens. Bujňáková (2010) underlines the insatiable role of agriculture in the cultivation of agricultural land and citizens' high-quality nutrition. These meaningful tasks of agriculture are fully taken into consideration by rural women involved in undertaken research. At the management of companies, they do orient their attention first of all on the fact, that Slovakia is considered as the country with strong agriculture background and also that the state can ensure its food self-sufficiency. FAO (2011) deals with certain recent challenges of agriculture and among those most serious is alongside others listed the fact that women lack enough resources and business opportunities. In contrary to this FAO conclusion, Slovak rural women do not feel this kind of disadvantage. They consider themselves emancipated. They pose with a high level of self-awareness and their access both to the production resources, as well as to financial resources is considered as good. According to our research, any discrimination in this respect is refused. In individual states of the world, is rather complicated to assign that what is the share of rural women to the development of the respective agricultural sector (Doss, 2011). The results of our research are documenting that share of rural women on the realization of agricultural activities is so far symbolic, especially if we speak about the top managerial and ownership positions, their shares on cultivated land, rural employment, or on rearing farm animals.

Jacková et al., (2016) wrote that tertiary agricultural education achieved about $8.4 \%$ more women than men in 2014. According to our findings, the results are analogical when we take into consideration the achieved education, as in the group of rural women are graduated from agricultural universities 29\%. This finding is also in line with author Schneiderova (2015), who states, that nowadays are completing university education far more women than men, even frequently with better results. With this author, we also coincide in the statement that every businesswoman is in a similar age as a man when she/he is acting in the supreme managerial position. This virtually means age about fifty years and so woman and man have behind of their relatively long professional carrier.

\section{CONCLUSION}

Women doing business in agriculture dispose of with considerable knowledge and experience in the agricultural and food sectors. The average of years of practical experience in our group of rural women reached 23 years. If we deal with the analysis of the gender differences, the rural women do consider their overall business rights are equal when asking for various kinds of state or EU supports, for approval of projects, etc.

Stemming from the achieved results of a carried out survey it had been formulated following conclusions: 1 . It is important to strengthen processes that promote the economic development of rural women and their managerial and social inclusion to overcome the overhelming representation of men in the agribusiness sector. 2 . Rural women dealing with business in the field of agriculture and food processing industry should intensively cooperate with young people, especially with females at the universities and vocational schools in the form of delivering lectures, organizing workshops, and practical activities in their farms. With this could be enhanced presence of young people including of women in the sector. In addition, the agricultural environment could be for future young farmers more attractive. 3. It is necessary to strengthen institutional support agencies to proactively address women's needs. In this respect, it is important to involve rural women in the work of associations and clusters through which rural women could enforce their requirements and needs having in mind the improvement of their respective businesses. The changing nature of farming as a profession has an impact on agricultural education changes too. It allows women to establish their professional careers in the field of their interest. The accessibility of training is supporting them to be able to embrace new technologies and managerial techniques. With this, their low representation in the managerial and ownership position in the sector can be significantly changed in comparison with recent unfavorable results revealed by this research.

\section{REFERENCES}

Buchta, S. 2013. Agrárna zamestnanost' a možnosti tvorby nových pracovných miest (Agrarian Employment and Opportunities for New Job Generations). Ekonomika pol'nohospodárstva, vol.13, no. 2, p. 51-68. Available at: https://issuu.com/vuepp/docs/ep_2_2013/51. (in Slovak)

Bujňáková, M. 2010. Postavenie pol'nohospodárskych podnikov vekonomike SR. Prosperita pol'nohospodárskej výroby pre zabezpečenie trvalo udržatel’ného rozvoja regiónov, p. 21-29. Available at: https://www.pulib.sk/web/kniznica/elpub/dokument/Kotulic1 1/subor/02.pdf (in Slovak)

Doss, C. 2011. The role of women in agriculture. Rome: Food and Agriculture Organization of the United Nations. (ESA Working Paper No. 11-02). Agricultural Development Economics Division. The Food and Agriculture Organization of the United Nations, p. 2-12. Available at: http://www.fao.org/docrep/013/am307e/am307e00.pdf. 
Fares, J., Gauri, V., Jimenez, E. Y., Lundberg, M. K. A., McKenzie, D., Murthi, M., Ridao-Cano, C., Sinha, N. 2007. World development report 2007: development and the next generation (Russian). The World Bank, vol. 1, p. 162-163. Available

at: https://documents.worldbank.org/curated/en/70928146813770 7723/World-development-report-2007-development-and-thenext-generation.

FAO. 2011. State of Food and Agriculture 2010-11: Women in Agriculture-Closing the Gender Gap for. Food \& Agriculture Organi, 160 p. Available at: http://www.fao.org/3/i2050e/i2050e.pdf.

Green report. 2017. Správa o polnohospodárstve a potravinárstve v Slovenskej republike za rok 2016 (Zelená správa). Ministerstvo pôdohospodárstva a rozvoja vidieka Slovenskej Republiky (Green Report about the State of Agriculture anf Food Industry in Slovak Republic in 2016). Bratislava. Avalible at: https://www.mpsr.sk/download.php?fID=14451 (in Slovak)

Grznár, M., Szabo, L. 2012. Konkurencieschopnost' agropotravinárstva a problém obnovy a využívania fixných aktív (The Competetiveness of Agribusiness Sector and the Problems of Renewal and Utilisation of Fix Assets). Stratégia rozvoja agropotravinárstva a konkurenčná schopnost' agropotravinárskych podnikov I. Bratislava, Slovakia : Vydavatel'stvo EKONÓM, Ekonomická univerzita Bratislava, (in Slovak)

ILO. 2018. Available at: http://ilo.org/global/about-theilo/lang--en/index.htm.

Jacková, S., Kadlečíková, M., Košuda, J., Juríčková, Z. 2016. The state of rural women and their role in the achievement of food safety. In: International Scientific Days 2016. The AgriFood Value Chain: Challenges for Natural Resources Management and Society, p. 47-53. https://doi.org/10.15414/isd2016.s1.03

Kadlečíková, M., Veselá, A. 2011. The Role of Rural Women in Agriculture and Rural Development in Europe and Central Asia. Acta Oeconomica et Informatica, vol. 14, p. 4346. Available

https://ageconsearch.umn.edu/record/268751/.

Patil, B., Venkatachalapathi, S. B. 2018. Role of women in agriculture. IJAR, vol. 4, no. 12, p. 109-114. Available at: https://www.researchgate.net/profile/Basavaraj_Patil10/public ation/329916126_Role_of_Women_in_Agriculture/links/5c2 31dc7a6fdccfc70690d75/Role-of-Women-in-Agriculture.pdf.

Robertson, B. 2017. Why Women are taking the centre field in farming. Available at: https://theconversation.com/whywomen-are-taking-centre-field-in-farming-73932.

Schneiderová, B. 2015. Zoči voči mužom (Face to face to men). Bratislava: Motýl', p. 19. (in Slovak)
Siegel, S., \& Castellan, N. J. (1988). The case of k related samples. Nonparametric statistics for behavioral sciences. New York: McGraw-Hill, 170-4.

Siiskonen, P. (1996). Overview of the socio-economic position of rural women in selected central and eastern European countries. Food and Agriculture Organization of the United Nations: Rome.

Statistical Office of Slovak Republic. 2018. Farm structure survey 2016 - typology of farms. Bratislava, Slovakia : Headquarters Bratislava, 57 p. Available at:

Szabo, L', Grznár, M. 2015. Pracovné sily a výkonnost' pol'nohospodárstva v SR (Labour and performance of agriculture in the Slovak Republic). Ekonomika pol'nohospodárstva, vol. 15, p. 3. (in Slovak)

Szreder, M. 2004. Methods and techniques of opinion polls”. Warszawa . Polskie Wydawnictwo Ekonomiczne, p. 238. ISBN 83-208-1515-0. (in Polish)

\section{Acknowledgments:}

This research was funded by research grant: VEGA $1 / 0802 / 18$, Corporate social responsibility and innovation activities focused on decreasing food losses with regards of environmental issues.

\section{Contact address:}

*Zuzana Kapsdorferová, Slovak University of Agriculture in Nitra, Faculty of Economics and Management, Department of Management, Trieda A. Hlinku 2, 94976 Nitra, Slovakia, Tel. +421 37641 4131,

E-mail: zuzana.kapsdorferova@uniag.sk

ORCID: https://orcid.org/0000-0002-4244-5695

Silvia Jacková, Slovak University of Agriculture in Nitra, Faculty of European Studies and Regional Development, Trieda A. Hlinku 2, 94976 Nitra, Slovakia, Tel. +421376414568

E-mail: silvia.jackova@uniag.sk

ORCID: https://orcid.org/0000-0003-3685-2769

Petronela Švikruhová, Slovak University of Agriculture in Nitra, Faculty of Economics and Management, Department of Management, Trieda A. Hlinku 2, 94976 Nitra, Slovakia, Tel. +421 37641 4134,

E-mail: petronela.svikruhova@uniag.sk ORCID: https://orcid.org/0000-0003-1785-040 